\title{
ENUNCIAČ̃̃O SATÍRICO-BURLESCA SEISCENTISTA: POSICIONAMENTO E POSIÇÃO ENUNCIATIVA NO DISCURSO CONSTITUINTE LITERÁRIO
}

André da Costa LOPES ${ }^{1}$

\section{INTRODUÇÃO}

Este trabalho estuda questões relacionadas à noção de posicionamento discursivo e de posição enunciativa em enunciados satírico-burlescos de Antônio da Fonseca Soares. Trata-se de um autor do período Barroco, reconhecido por uma vasta produção discursiva literária e por uma trajetória de poeta mundano e escritor espiritual. Interessa-nos, neste estudo, a produção discursiva satírico-burlesca, a qual entendemos como uma identidade enunciativa (CHARAUDEU; MAINGUENEAU, 2014) pertencente ao posicionamento discursivo Barroco.

Considerando as especificidades dos discursos constituintes, o posicionamento é um modo de configuração de certas zonas discursivas no interior de um campo discursivo e também um conjunto de normas enunciativas que regulam as práticas socio-discursivas. Daí a proximidade dessa noção com a de comunidade discursiva, já que há um envolvimento recíproco entre o discurso constituinte e os produtores desse discurso.

Ademais, os discursos constituintes caracterizam-se por instituírem sua própria condição de existência. Por isso, gerenciam sua emergência no interdiscurso e sua posição de discurso de autoridade, numa constante dinâmica de autolegitimação. Configura-se, nesse processo, um arquivum de fontes fundadoras, de autores consagrados e de grandes obras.

Toda fonte fundadora tem, de certa maneira, relação com o absoluto que sustenta os discursos constituintes: a Razão, Deus, a Verdade, o Belo. Maingueneau (2000) afirma que, ao enunciar a partir de um discurso constituinte, os sujeitos assumem a posição de porta-vozes que falam em nome da religião, da ciência, da filosofia e da literatura. Portanto, no âmbito da autoralidade, um auctor deve se aproximar da fonte fundadora, mãe dos princípios estéticos e ético-políticos que norteiam as práticas sócio-discursivas, para legitimar-se.

1 E-mail: dacostta@hotmail.com 
O nome Antônio da Fonseca Soares, ao estar associado, a um poeta-mundano do século XVII, revela um posicionamento no discurso constituinte literário seiscentista e também o pertencimento a uma identidade enunciativa satírico-burlesca. O domínio do código retórico-poético, que norteia o regime de autoria, aproxima-o das principais fontes fundadoras dessa produção literária: a Retórica e a Poética de Aristóteles. Na mesma lógica, os enunciados poéticos, ao seguirem as normas de composição de uma poética do riso, estabelecem relação privilegiada com outra fonte também aristotélica: a Comédia.

Tendo em vista essas considerações, partimos do principio de que o pertencimento a uma determinada zona discursiva situada em um discurso constituinte literário revela-se nas camadas da enunciação. É pela cena de enunciação, ou seja, pela articulação discurso, gênero de discurso e cenografia, que o enunciado literário se constitui como produto de um ato enunciativo. A partir daí, torna-se possível vislumbrar lugares de fala, modos de enunciar específicos e a emergência de sujeitos enunciadores pelos quais se pode demarcar certo espectro de posições enunciativas.

Neste trabalho, objetivamos traçar relações entre as noções de posicionamento e de posição enunciativa no discurso constituinte literário. Para tal, tomamos como ponto de partida uma discussão a respeito do processo de autoralidade, sobretudo em relação à instância autoral auctor. Nessa perspectiva, a leitura dos enunciados poéticos fonsequianos mostram como as camadas enunciativas revelam normas enunciativo-discursivas que regulam a produção, a recepção e a circulação de uma enunciação satírico-burlesca.

As discussões estão fundamentadas no quadro teórico-metodológico da Análise do Discurso (AD), sobretudo na perspectiva enunciativo-discursiva, postulada por Dominique Maingueneau.

\section{DISCURSO LITERÁRIO COMO DISCURSO CONSTITUINTE}

A proposta de Maingueneau (2000, 2008b, 2012) com a noção de discurso constituinte é, principalmente, criar uma unidade consistente que possa enquadrar discursos, como o religioso, o filosófico, o literário e o científico. Por isso, é preciso encontrar especificidades comuns a todos eles e, além disso, diferenciá-los de outros discursos.

Uma peculiaridade essencial dos discursos constituinte está no fato de não reconhecerem outra autoridade além de sua própria, de não reconhecerem nenhum discurso acima deles. Contudo, isso não significa que não haja interação entre os discursos constituintes e não constituintes. Pelo contrário, há uma relação interdiscursiva constante entre eles, porém, como afirma Maingueneau 
(2008b, p. 37), “faz parte da natureza dos discursos constituintes negar essa interação ou pretender submetê-la a seus próprios princípios".

Diante dessa lógica de funcionamento, os discursos constituintes se impõem como fonte de autoridade e, como tal, transformam-se em argumentos legitimadores prontos a serem apropriados por outros discursos. Exemplo mais notório disso em nossa sociedade, é o discurso jornalístico que vez ou outra se apropria do discurso científico, filosófico ou até mesmo do literário para autorizar suas falas.

Os discursos constituintes mobilizam em sua autoconstituição e a cada enunciação particular um conjunto de valores legitimadores, aos quais Maingueneau (2008b) sintetiza com o termo archeion. Esta palavra possui em sua etimologia sentidos, como poder, fonte, arquivo e memória. Diante dessa associação, esses discursos são considerados, ao mesmo tempo, fundados por si mesmo, fonte de autoridade e memória. Por isso, jamais se equiparam ou se situam em posição inferior àquelas dos discursos institucionalizados. Isso significa que, para garantir o sucesso de tal estatuto, é preciso um processo de gerenciamento dessa superioridade discursiva em relação aos demais discursos e aos próprios discursos constituintes.

Ao longo da história, é possível notar os embates entre discursos constituintes, principalmente no que se refere à pretensão de ser o único detentor do archeion. Esse é o caso, por exemplo, nos primórdios da Era Moderna, da derrocada do discurso teológico em face do científico. Todavia, há também embates e filiações, seja entre os próprios discursos constituintes, seja em zonas discursivas no interior de um dado discurso constituinte. Nesse último caso, são emblemáticas as filiações e rupturas entre posições estéticas dentro do campo discursivo literário com a finalidade de legitimar a emergência de novas correntes.

Se por um lado os discursos constituintes se autolegitimam no próprio ambiente discursivo; por outro, eles também se alimentam da autoridade advinda de instâncias legitimadoras "externas”, como a Verdade, Deus, o Belo e a Razão.

Conforme Maingueneau (2008b, 2012), a constituição dos discursos constituintes pode ser apreendida a partir de duas dimensões: a constituição, como processo pelo qual o discurso se instaura, constituindo sua própria emergência no interdiscurso; e os modos de organização e de coesão discursiva que possibilitam a constituição de uma totalidade textual. Para que isso ocorra, é preciso considerar que esses discursos possuem certa função, a saber: dispõe da mais forte autoridade e participam de situações de comunicação de uma sociedade.

Em razão disso, o discurso constituinte configura-se como um campo discursivo capaz de autorregular-se instituindo suas próprias normas de funcionamento e, ao mesmo tempo, tornando possível um espaço de práticas discursivas. Tais práticas requerem um conjunto de produtores e leitores autorizados a mani- 
pular o quadro hermenêutico de tais discursos. Isso significa ter conhecimento máximo dos modos de leitura e produção discursiva.

A esse grupo seleto que têm sua existência em função do discurso constituinte, mas também age no sentido de garantir a existência e a legitimação desses discursos, Maingueneau (2012) dá o nome de comunidades discursivas. Elas são divididas em dois tipos intimamente relacionados: as que gerem e as que produzem o discurso. Assim, os discursos constituintes não articulam apenas uma rede de grandes autores, "mas uma variedade de papéis sociodiscursivos encarregados de gerir enunciados: por exemplo, no caso da literatura, as críticas literárias de jornal, os professores, as livrarias, os bibliotecários etc".

Assim como todo o discurso constituinte, o discurso literário mantém uma relação dupla com o interdiscurso. Isso se dá porque as obras se alimentam de outros textos por meio de procedimentos, como citações, imitações ou investimento em um gênero e, necessariamente, tornam-se objeto de interpretação, citação e reemprego. É um movimento dialético, pelo qual as obras, ao mesmo tempo em que se apropriam de outros discursos, tornam-se potencialmente objeto de apropriação, de citação e interpretações.

Essa dinâmica revela um estatuto pragmático, que faz com que a obra seja um texto que necessariamente deva ser comentado, pois o discurso constituinte prevê tal prática como um processo de legitimação de si mesmo. Nesse caso, o interprete não é um simples leitor autossuficiente. Pelo contrário, ao se posicionar como sujeito-interprete, ele está envolvido no processo instaurado pelo discurso constituinte que prevê que seus enunciados sejam interpretáveis e que determina modos de leitura dentro de sua lógica enunciativa.

A esse respeito, Maingueneau (2012) considera que o texto só será legitimado ao ser tomado num quadro hermenêutico. Isso quer dizer que, para isso, o texto deverá ser digno de interesse, ser considerado singular; deverá trazer em si uma mensagem transcendente e oculta que trate de questões relativas a fundamentos.

Um texto que deixar de ser objeto de interpretação cessará de ser enigmático e, por conseguinte, perderá seu status de fonte capaz de revelar mensagens importantes para a coletividade. Portanto, estará fadado ao esquecimento por perder uma característica que lhe confere pertencimento ao discurso constituinte. Inversamente, o aumento das interpretações, deve gerar cada vez mais interpretações, causando uma reação em cadeia, que garantirá a legitimidade do texto e também seu pertencimento.

Diante disso, o quadro hermenêutico se firma como algo pertencente à dinâmica dos discursos constituintes e, sobretudo, como instrumento legitimador desses discursos nas próprias comunidades discursivas. 
cada intérprete legitima-se mediante cada interpretação bem-sucedida; ao fazê-lo, ele relegitima seu lugar e, ao mesmo tempo, relegitima a condição do texto comentado como membro do quadro hermenêutico, para, além disso, relegitima o próprio quadro hermenêutico (MAINGUENEAU, 2012, p.75).

O quadro hermenêutico define então modos de leitura e também determina quem está autorizado a interpretar o discurso literário. Nessa dinâmica, Maingueneau (2012) observa que o texto literário beneficia-se de uma hiperproteção, ou seja, qualquer violação às leis do discurso será entendida como um efeito de sentido a ser decifrado.

Portanto, diante desse quadro hiperprotegido, qualquer transgressão discursiva ou de convenção de gênero, funcionará como um índice interpretativo, como uma espécie de implícito que leva o leitor/intérprete a pensar que tudo não passa de um procedimento composicional inerente ao texto literário que ele deve explicitar.

Maingueneau (2012) afirma haver em tais procedimentos uma historicidade; pois, por meio tal processo, pode-se vislumbrar as normas em vigor no momento da criação. Isso quer dizer que algumas obras, em seu surgimento, não se beneficiam dessa hiperproteção hermenêutica e são, em princípio, renegadas. Para pensarmos em apenas um exemplo em solo brasileiro, o autor Lima Barreto não teve a maioria de seus escritos valorizados pela crítica coeva. Foi preciso que sua obra fosse legitimada por um novo paradigma estético, o Modernismo, que por sua vez se apropriou dos escritos barreteanos como arautos legitimadores do próprio movimento.

Hoje, novamente, Lima Barreto está em voga muito mais por se enquadrar numa série de discussões advindas do campo dos estudos culturais que tem como objeto de estudo os discursos multiculturais do que por ser autor modernista. Nessas condições sócio-históricas de produção, a obra desse autor seria uma das percursoras no que diz respeito à denúncia sobre as condições de vida do homem e da mulher negra no fim do século XIX e uma das fundadoras de uma estética literária afro-brasileira. Estabelece-se, assim, um novo quadro de leitura possível para os escritos desse autor.

\section{POSICIONAMENTO E POSIÇÃO ENUNCIATIVA NO DISCURSO CONSTITUINTE LITERÁRIO}

Embora o discurso constituinte crie a ilusão de estar fechado em si mesmo e de ser um discurso com superioridade inquestionável, ele se constitui no interdis- 
curso e nele cria mecanismos constantes de autolegitimação. Com isso, é inevitável que haja embate com outros discursos. A esse respeito, Maingueneau (2000) afirma que o conflito não ocorre apenas entre discursos não constituintes e constituintes, ele acontece no interior dos próprios discuros constituintes. Isso porque estes últimos se organizam como um campo, como um espaço de concorrência permanente, no sentido de um jogo de filiações, embates e ilusões de neutralidade, entre diversos posicionamentos.

Quando se considera o campo discursivo, posicionamento tem a ver com um lugar e um modo de produção discursiva específico no interior do discurso constituinte. Em razão disso, Maingueneau (2000, 2008, 2012) os aproxima, num certo didatismo, do que os estudos literários consideram como escolas ou períodos.

Entretanto, não se trata apenas de delimitar um período com certo número de autores e obras consagradas ou certas regularidades estéticas. O que pretende Maingueneau $(2000,2008,2012) \mathrm{com}$ a noção de posicionamento é mostrar o modo de configuração de certas zonas discursivas no interior do campo e a relação delas com as práticas sócio-discursivas.

Daí a proximidade dessa noção com a de comunidade discursiva, já que há um envolvimento recíproco entre o discurso constituinte e os produtores desse discurso. O discurso constituinte é um espaço de subjetivação que "recruta" um conjunto de sujeitos leitores/produtores e, assim, torna-se produtor e produto de suas comunidades. $\mathrm{O}$ modo de emergência, circulação e consumo de tais discursos ocorre em um espaço restrito, mas adquire alcance global.

Ao discorrer sobre trajetória do escritor no campo literário, Maingueneau (2001) evoca a metáfora da tribo. Por dizer respeito a um agrupamento local, vinculado e desvinculado das normas de interação e dos valores sociais, esses pequenos grupos criam um universo único, uma coerência própria.

A vida literária está estruturada nessas tribos que se distribuem pelo campo literário com base em reivindicações estéticas distintas: círculo, grupo, escola, cenáculo, bando, ou academias. A existência de uma tribo não implica necessariamente a frequência assídua aos mesmos lugares. Ela pode resultar de trocas de correspondências, de encontros ocasionais, de semelhanças nos modos de vida, de projetos convergentes. Existe desse modo certo número de 'tribos invisíveis', que desempenham um papel de arena literária.

Se o posicionamento gerencia a própria prática discursiva, ele também deve negociar, no interior do campo discursivo e para além dele, o seu próprio archéion. É preciso legitimar sua autoridade a cada enunciação e constituir um arquivum, com fontes fundadoras, grandes obras, e auctores, gerando um espaço de memória. 
O estudo realizado por nós, em Lopes (2019), mostra que o discurso literário produzido no século XVII organiza seu arquivum em torno de uma fonte fundadora: os trabalhos de retórica e poética aristotélicos, depois atualizados por autores latinos, do medievo, renascentistas e seiscentistas. Dessa grande rede de releituras, o posicionamento barroco organiza para si sua própria rede de filiações, mas mantém a norma basilar que distinguia o discurso literário das demais práticas linguageiras: o princípio da imitação. Princípio que se revestia de uma dupla função, imitar e instruir.

O imitar e o instruir estão relacionados, ao mesmo tempo, com princípios estéticos e ético-políticos. Isso porque o posicionamento Barroco mantém uma relação interdiscursiva com código moral da Igreja Católica e o civilizatório do discurso humanista que regulavam as relações interpessoais da Sociedade de Corte. No âmbito estético, a proximidade com a fonte fundadora dava legitimidade a esses discursos, mas no processo de filiações ocorrem também redefinições. É o caso da metáfora ${ }^{2}$. Essa palavra-conceito (ANGERMULLER, 2016) em Aristóteles ([19-]) é concebida como signo de elegância do discurso, entretanto recomenda-se a usá-la com parcimônia. Isso porque o excesso pode obscurecer a escrita, o que infringi a norma autoral da clareza, simplicidade e unidade que rege os discursos classicistas.

Ocorre que o discurso constituinte literário seiscentista aproxima a metáfora da noção de agudeza. O que significa dizer que as produções escritas e mesmo algumas práticas linguageiras no interior dos grupos letrados deveriam revestir-se de efeitos de sentidos estabelecidos por sofisticadas relações semânticas. O que deveria obscurecer o discurso, para os preceptistas seiscentistas; na verdade, tornava-o engenhoso. Isso definia um estatuto enunciativo em que o sujeito-autor e o sujeito leitor deveriam demonstrar conhecimento máximo do código retórico-poético, que regulava as práticas verbais. A "transgressão" a fonte fundadora transforma-se num critério estético e de autoralidade.

Forma-se, a partir daí, uma comunidade discursiva com um grupo seleto de produtores, capazes de manipular com destreza o código retórico-poético. Eles têm uma habilidade entendida por Maingueneau (2012) como vocação enuncia-

2 A respeito da redefinição da metáfora aristotélica pelo discurso literário seiscentista, conferir LOPES, Andre da Costa; NOGUEIRA, Andréa Scavassa Vecchia Nogueira. O luzir do discurso engenhoso: a noção de metáfora aguda segundo a preceptiva retórico-poética seiscentista. In MORAES, Carlos Eduardo Mentes; BULHÒES, Ricardo Magalhães (Org). Capítulos Lusoamericanos: História, Filologia, Literatura e Linguística. São Paulo: UNESP - Campus de Assis, 2019. 
tiva e que a recepção seiscentista entende por engenhosidade. O sujeito-autor engenhoso para a preceptiva barroca é aquele que tem o conhecimento máximo da arte e do decoro dos gêneros e a capacidade de atualizar os discursos-modelo de maneira ímpar. Por meio da vocação enunciativa, um sujeito-autor se distingue dos demais enunciadores e emerge como uma força criadora singular.

Ao constituir para si seu próprio archéion, o posicionamento configura uma rede de gêneros de discursos. Maingueneau $(2000,2012)$ afirma haver, na composição de um arquivum, uma hierarquia de gêneros, visto que o discurso constituinte recobre para si um espaço de produção heterogêneo. O discurso literário constituinte, por exemplo, legitima-se por meio de um conjunto de grandes obras. Em alguns casos, algumas recebem o status de fonte legitimadora ou arquitextos ao se tornarem objeto de um incessante debate entre posicionamentos. Contudo, há gêneros menos "nobres", cuja função é comentar, divulgar ou ensinar preceitos estéticos.

Qualquer abordagem da literatura entendida como prática sociodiscursiva não deve desconsiderar as condições de produção e muito menos os suportes e meios de veiculação das obras. O mídium (MAINGUENEAU, 2012) intervêm na própria produção dos sentidos. Nesse sentido, o discurso literário constituiu-se historicamente por uma tradição oral, seguida de uma tradição escrita. Esta última passou por um processo que engloba a cultura manuscrita, a impressa e a informática.

Portanto, o posicionamento como uma zona de produção no interior de um discurso constituinte demarca para si uma rede de relações interdiscursivas, um conjunto de gêneros e midiuns, modos de enunciar e uma gama de práticas sóciodiscursivas circunscritas numa dimensão sócio-histórico-cultural que demarcam o lugar, nem sempre instável, de uma identidade produtora.

Santiago (2000), ao discorrer sobre o discurso literário latino-americano, situa-o no entre-lugar. Num espaço antropofágico que se alimenta do espólio literário da metrópole para transformá-lo em algo singular. Sugere, a partir dessa hipótese, um novo quadro hermenêutico para os críticos: trocar a prática de leitura, até então vigente, que consistia em localizar fontes e influências nos textos por outra: atentar-se às rupturas estéticas, aos traços de submissão e resistência criativa que transformam o Mesmo em Outro.

Entre o sacrifício e o jogo, entre a prisão e a transgressão, entre a submissão ao código e a agressão, entre a obediência e a rebelião, entre a assimilação e a expressão - ali, nesse lugar aparentemente vazio, seu templo e seu lugar de clandestinidade, ali, se realiza o ritual antropofágico da literatura latino-americana (SANTIANO, 2000, p.26). 
Enquanto Santiago (2000) concebe a emergência da identidade do discurso literário latino-americano no espaço fronteiriço do entre-lugar. Maingueneau (2001, 2008b, 2010, 2012) radicaliza ao afirmar que os discursos constituintes legitimam sua autoridade/identidade justamente no espaço fronteiriço e instável do interdiscurso. A partir dessa hipótese, desenvolve a noção de paratopia, por meio da qual se pode vislumbrar os limites instáveis dos posicionamentos no campo discursivo e a influência dessa instabilidade constitutiva nas práticas sócio-discursivas.

Por essa razão, Maingueneau (2010) declara que a paratopia pode manifestar-se em dois níveis complementares: no nível do discurso constituinte e no nível de cada produtor de texto posicionado num discurso constituinte. No primeiro caso, trata-se de um pertencimento instável no campo discursivo pela necessidade constante de legitimação da autoridade/identidade constituinte em relação aos demais discursos. No caso do produtor de texto, uma vez posicionado num discurso constituinte, ele deve construir para si uma identidade por meio das formas de pertencimento/não pertencimento à sociedade, de obediência/desobediência às normas de autoralidade. Enquanto para um Médico o diploma é indício suficiente para lhe conferir autoridade, para filósofos, cientistas, lideres religiosos e escritores o vínculo institucional é insuficiente para legitimá-los.

A imagem dos atores literários, como uma tribo ilustra bem de que maneira certos grupos configuram um modo de vida e certos ritos genéticos de produção. Para um escritor barroco é fator primordial a proximidade com o poder real. Isso lhe garante um modo de vida parasitário, visto que depende de mercês para sobreviver, mas também lhe confere status de escritor real. Desse modo, a proximidade com o poder institucional e com as fontes fundadoras do discurso constituinte são condições primordiais para que um escritor tenha sua produção legitimada. A despeito disso, para se tornar um auctor é preciso que terceiros falem dele. É nesse caminho tortuoso e instável, ou seja, é nesse espaço paratópico que o escritor deve gerir sua trajetória. Diante disso, vale repetir as palavras de Maingueneau (2012): a paratopia não é a ausência de todo lugar, mas uma negociação entre o lugar e o não lugar.

Visto dessa maneira, o posicionamento pode ser considerado uma identidade enunciativa forte (CHARAUDEU; MAINGUENEAU, 2014) que se revela nas camadas da enunciação: no discurso, no gênero de discurso e na cenografia. $\mathrm{O}$ enunciado literário, como produto de um ato enunciativo, remete a um lugar de fala e a modos de enunciar específicos de certas zonas de discurso. A partir de tais constatações, é possível vislumbrar a emergência de sujeitos enunciadores pelos quais é possível demarcar certo espectro de posições enunciativas.

No caso dos discursos constituintes, Maingueneau (2000) afirma que os sujeitos assumem uma posição de porta-vozes que falam em nome da religião, da 
ciência, da filosofia e da literatura. Isso significa falar em nome de um OUTRO para além do qual só há o indizível. Em outras palavras, significa aproximar-se do absoluto que norteia tais discursos: de Deus, da Razão, da Verdade, e do Belo. Trata-se de um mecanismo determinado pela condição paratópica que não permite que esses sujeitos se autorizarem apenas por si mesmos, daí a necessidade de aparecerem ligados a uma fonte legitimante ou a um discurso fundador. Estas são as pontes que levam aos fundamentos basilares dos discursos constituintes. É o caso da relação da produção discursiva literária barroca com a opus aristotélica.

A ideia de um espectro de posições-enunciativas que emergem das camadas de enunciação ou, nas palavras de Maingueneau (2012), da cena de enunciação, remete ao processo de autoralidade. Essa noção traz em si três instâncias autorais que se articulam ao responsável pelo discurso, o autor-responsável; ao produtor do discurso vinculado às práticas sócio-discursivas, o autor-ator, que neste trabalho entenderemos como escritor; e a uma instância, que de certo modo, transcende as duas primeiras, o auctor.

Em se tratando de discurso constituinte, o auctor assume a posição de porta-voz dos fundamentos enunciativos que constituem os posicionamentos. Ele legitima ao mesmo tempo em que é legitimado pelo discurso. Por isso, um auctor só atinge plenamente esse status se terceiros falarem dele; se, em seu entorno, girarem certo número de narrativas, por meios das quais se projeta uma imagem de autor (MAINGUENEAU, 2010).

O autor-responsável investido na autoridade enunciativa de um auctor aciona, no conjunto de enunciados em torno desse nome, a função-autor (FOUCAULT, 2013). Isso porque sua proximidade com a fonte fundadora do discurso constituinte determina certos modos de leitura, dentro dos padrões de quadros hermenêuticos específicos. Além disso, o auctor é responsável por dar coerência, unidade e identidade a discuros, cuja produção é associada a ele.

Foucault (2013) chama de posição-sujeito os signos que remetem ao autor no discurso. Se pensarmos na cena de enunciação da produção poética satírico-burlesca seiscentista, o autor-responsável pode remeter, ao mesmo tempo, ao auctor e ao poeta satírico, dispersando-se no enunciado poético, por conta das vozes que emergem das relações interdiscursivas.

Acomodando-se em camadas enunciativas, a cena de enunciação remete ao tipo de discurso, ao gênero de discurso e a cenografia. Esta última é a configuração de uma cena de fala vinculada ao estatuto enunciativo do gênero de discurso, mas que tematiza sua própria enunciação a cada novo ato de discurso. No enunciado literário, a cenografia instaura-se como a cena de fala em que se revela o enunciador (MAINGUENEAU, 2012) e, por isso, é o lugar da manifestação de um ethos discursivo e da consequente dispersão do sujeito-autor no discurso. 
Tendo em vista, o primado do interdiscurso, o enunciado é de natureza interdiscursiva, portanto é revelador de uma pluralidade de vozes. É nele e por ele que a voz do sujeito-autor se rarefaz. Contudo, em razão das redes de filiações discursivas e de signos de pertencimentos (MAINGUENEAU, 2008), é possível identificar o lugar de onde se enuncia.

\section{ANTÔNIO DA FONSECA SOARES: A EMERGÊNCIA DE UM AUCTOR NA ENUNCIAÇÃO SATÍRICO-BURLESCA}

Antônio da Fonseca Soares é um autor do período Barroco, cuja produção discursiva é dividida em uma fase mundana e outra religiosa. Nesta última, a responsabilidade autoral é vinculada ao nome religioso Frei Antônio das Chagas. Neste trabalho, interessa-nos a produção mundana, sobretudo a satírico-burlesca.

Nesta zona de produção discursiva, foi considerado um autor modelo. Entendemos que esse status se deve a uma capacidade de criar efeitos de sentido singulares em razão do domínio do código estético, centrado nos saberes retórico-poéticos de tradição aristotélica, e ao reconhecimento, por parte da recepção, dessa vocação enunciativa. Na lógica de funcionamento dos discursos constituintes, dominar o código estético significa, ao mesmo tempo, enquadrar-se ao quadro hermenêutico e aproximar-se da fonte fundadora do código de composição.

A maestria e o domínio do burlesco rendeu a Antônio da Fonseca Soares o apelido de Capitão Bonina. Tal apelido está relacionado à sua trajetória como poeta burlesco. Isso porque foi soldado e poeta durante um tempo de sua vida. Serviu na guerra de restauração da coroa portuguesa ante a dominação espanhola e desempenhou papel decisivo numa operação militar em que se aprisionou um tenente e nove soldados. Tal ato rendeu-lhe a patente de capitão. Ocorre que, mesmo em campanha, Antônio da Fonseca Soares escrevia romances de galanteio a damas da corte e a freiras, e levava vida desregrada. Desse modo, o nome Capitão Bonina tornou-se uma espécie de expressão metafórica para designar uma imagem de poeta burlesco.

O posicionamento Barroco imprime sua identidade no campo discursivo por pertencer à estética da imitação e por relativizar a noção de clareza e simplicidade reivindicada pelo Classicismo. Arte, decoro e engenho são as engrenagens que fazem girar o código de composição seiscentista. Em outras palavras, o domínio do código retórico-poético, o respeito ao estatuto enunciativo dos gêneros de discurso, e a capacidade de atualizar de maneira singular um código estético fechado, centrado em modelos "fixos" são as bases para qualquer produção discursiva nesse posicionamento. 
As comunidades discursivas configuram-se num espaço social restrito aos letrados da corte, a serviço da Coroa ou da Igreja. O campo de produção, recepção e circulação de discursos centra-se nos eventos palacianos e religiosos, nas academias de letrados ou nas trocas de correspondências. A proximidade com o poder real concebe ao escritor, além da possibilidade de viver apenas da arte, o prestígio de ser artista do reino.

Entretanto, quando pensamos em posicionamento Barroco, devemos desdobrá-lo em, pelo menos, três identidades enunciativas: a primeira adentra o campo da espiritualidade; a segunda, o campo dos gêneros graves; a terceira o campo dos gêneros baixos.

No que diz respeito às duas últimas, no século XVII, a teoria da divisão dos estilos retóricos abriu caminho para que a arte poética pudesse explorar com certa liberdade a matéria torpe, vinculada aos vícios morais da sociedade (HANSEN, 1989; MUHANA, 1997). Desde Aristóteles, gêneros de discurso literários como a tragédia e a épica pertencem, por tratar assuntos sérios, aos gêneros graves e a comédia, por tratar temas joco-sérios, aos gêneros baixos ${ }^{3}$. De um modo mais geral, é a temática da poesia que define seu pertencimento aos gêneros graves ou aos baixos. Mas essa divisão não tem sua origem apenas na Arte Poética, ela possui longa tradição retórica, no que concerne ao gênero retórico demonstrativo, pelo qual se normatiza os modos de enunciar louvores e vitupérios.

Ao ser reconhecido como poeta burlesco, Antônio da Fonseca Soares tem sua produção discursiva vinculada a uma identidade criadora com normas de autoria particulares. O código retórico-poético perpassa toda produção discursivo-literária barroca, mas há algumas especificidades no que se refere aos gêneros baixos.

A base para a normatização de um código autoral para discursos cômicos está nas Artes Retórica e Poética de Aristóteles. No século XVII, o preceptista Tesauro (1992), a partir de poucas informações, apreende por tarefa reconstituir o livro perdido de Aristóteles: a parte na Arte Poética correspondente à comédia. No capítulo V da Arte Poética, Aristóteles ([19-], p. 246) a define nos seguintes termos:

a comédia é (...) imitação de maus costumes, não contudo de toda sorte de vícios, mas só daquela parte do ignominioso que é o ridículo. O ridículo

3 Neste trabalho, entendemos como gêneros baixos o conjunto de gêneros de discurso literários que exploram a temática cômica e que de maneira satírica ou burlesca buscam censurar vícios; e como gêneros graves o conjunto de gêneros de discurso literários de temática séria que lidam com o louvor a coisas consideradas virtuosas. 
reside num defeito e numa tara que não apresentam caráter doloroso ou corruptor. Tal é, por exemplo, o caso da máscara cômica feia e disforme, que não é causa de sofrimento.

Esse será o mote central para que Tesauro (1992) elabore uma poética do riso. É a partir dessa curta passagem que esse preceptista Barroco desenvolve algumas premissas centrais, a saber: a matéria do ridículo é o torpe; o riso se dá a partir de uma torpeza física em que está implícita uma torpeza moral. O pior é tema da comédia; distinguindo-se do melhor, que é tema da tragédia.

Além disso, também se baseando em preceitos aristotélicos, Tesauro (1992) desenvolve o conceito de riso urbano. Para o preceptista, qualquer forma de riso deve ser apresentada nesse registro. Isso porque o que dá o tom de urbanidade e de conversação civil a gracejos, facécias, burlas ou sátiras é o conhecimento da arte, ou seja, dos códigos de composição retórico-poéticos e do decoro dos gêneros de discurso literários que trazem em si os verossímeis poéticos e a adequação retórica para cada situação de enunciação. Máximas latinas como turpitudo sine dolore, minimeque noxia ${ }^{4}$ ou dicere turpie non turpiter 5 servem como termômetros reguladores do riso urbano tanto para a poesia burlesca quanto para a sátira. Desse modo, mesmo que os gêneros baixos sejam o lugar, onde se possa empregar com mais liberdade expressões populares, calões, obscenidades ou mesmo imoralidades; mesmo que nesse lugar os discursos marginalizados circulem sem muitas amarras, eles devem vir revestidos com o modo de enunciar urbano.

Ao compor para si um código de composição e um estatuto enunciativo particular, a identidade enunciativa satírico-burlesca também torna possível um conjunto de práticas sócio-discursivas distintas. Há uma apropriação dos gêneros de discurso literário pertencentes aos gêneros graves, mas há um de preferência: o romance. No século XVII, o romance era sinônimo de poesia vulgar, por ter uma origem popular e por se tratar de um gênero de discurso que se configurava como um poema narrativo, cuja principal temática era satírica e burlesca, com fortes marcas de erotismo.

No espaço social, ao poeta pertencente à "tribo" dos burlescos cabia uma vivência mundana. Ao discorrer sobre a tradição satírico-burlesca em Portugal, Miranda (2014) evidencia a vida mundana de alguns trovadores e poetas. No

4 Feiura sem dor, com o mínimo de prejuízo.

5 Dizer torpezas sem torpeza. 
século XIII, Afonso Eanes de Coton é descrito como um tabernário e frequentador de meretrizes e Pero da Ponte como Contumaz beberrão. Já no século XVII, dom Tomás de Noronha dissipou sua fortuna em uma vida libertina, Estevam Nunes de Barros foi freirático e mesmo Antônio Barbosa Bacelar, poeta grave, saudado como um Homero ou Virgílio Renascido, também participou da musa despudorada. Dentre eles está o burlesco Antônio da Fonseca Soares, "nobre de ascendência irlandesa, soldado, de feição estroina e dotado de excelente apetite sexual, seduzindo mulheres com seus poemas elegantes” (MIRANDA, 2014, p.146).

Vale pontuar que, muito mais do que falar de indivíduos empíricos, os discursos que giram em torno desses nomes dizem respeito a representações que se tinham sobre o poeta satírico-burlesco. Nesse sentido, a trajetória do poeta é marcada pela força de subjetivação do discurso constituinte literário que arregimenta para si um conjunto restrito de enunciadores, porta-vozes de seus fundamentos mais profundos.

Tendo em vista as especificidades do posicionamento Barroco e da identidade enunciativa satírico-burlesca, é possível identificar por meio da cena de enunciação traços de posições enunciativas no enunciado poético. Os enunciados a seguir dão indícios de uma posição genérica que remete a imagem social que se tinha do poeta burlesco:

É bem daqui para cima, que a dizer mais não me atreva que posto sou velhacão não quero falar de perna,

(SOARES, Antônio da Fonseca. Romance 28, in. Ms.2998)

Cobras, e lagartos Filis

foi mal que de mim dissestes

pois nunca fui lagarteiro

bem que grão lagarto sempre

(SOARES, Antônio da Fonseca. Romance 40, in. Ms.2998) 


\author{
Mas perdoai atrever-me \\ pois é de amor indício \\ que amante que não se atreve \\ nunca foi amante fino
}

(SOARES, Antônio da Fonseca. In. MALDONADO, 1992, pp. 456-460)

Nas partes destacadas, as posições enunciativas remetem ao poeta burlesco, pois a imagem que se fazia de tais escritores nos seiscentos está estreitamente ligada à prática de ações desregradas e à malícia joco-séria e erótica. A “tribo" dos burlescos é composta de personagens picarescos que perambulam por lugares marginalizados, junto a más companhias. O poeta burlesco vive em espaços paratópicos e deve estar próximo não da virtude ou de pessoas que ocupam as instâncias de poder, mas dos vícios e de pessoas marginalizadas.

A despeito disso, o sistema de mecenato que regula as práticas artísticas na Sociedade de Corte determina a existência de certo grupo de letrados em torno do poder real, em busca de prestígio social e legitimação autoral. Nessa lógica, o escritor legitima-se se estiver próximo as instâncias de poder, garantindo o ócio necessário a toda prática de escrita literária. Por isso, o grande número de enunciados literários laudatórios e a necessidade das dedicatórias que alimentam o discurso literário e que mostram a busca constante por legitimação num espaço instável afeito a mudanças constantes. No sistema de mecenato cair na graça ou cair em desgraça pode ser a face da mesma moeda, num ambiente no qual o poder político está sempre na iminência de uma derrocada.

Paradoxalmente, o poeta burlesco e satírico, embora subordinado à mesma lógica sociodiscursiva, parece sublevar certas determinações. Isso porque distanciam-se das instâncias de poder ao saírem do ambiente da corte e perambularem por lugares marginalizados e contestados pelo código ético-político vigente. Além disso, ao invés de louvar os distinguidos e o círculo de poder a eles relacionado, maldizem e ridicularizam tais personalidades e instituições. Expor-se ao perigo e jogar com as consequências disso são movimentos de um jogo paratópico e o motor de criação literária para esses escritores.

Talvez por isso as narrativas e lendas sobre Gregório de Matos e sobre o próprio Antônio da Fonseca Soares discorram tanto sobre suas personalidades. Boca do Inferno sintetiza a imagem de um escritor de personalidade forte que, de modo algum, aceitava os desvios morais dos poderosos do seu tempo. O poeta 
burlesco Antônio da Fonseca Soares é visto como um valdevinos zombeteiro, uma espécie de pícaro esclarecido sempre disposto a trazer novidades risíveis do submundo marginalizado que circunda a corte.

A ideia de que os poetas satíricos e burlescos se desprendem da dependência de seus mecenas ou de que podem manipular discuros interditados pelo código ético-político, nos dá a dimensão dos mecanismos de autonomia operados pelo discurso constituinte literário. Fato que faz com que o a enunciação satírico-burlesca tenha uma liberdade de expressão impensável num tempo de vigilância moral severa. Os enunciados abaixo podem ilustrar bem essa afirmação:

Vede lá quem Venus foi,

e quem foi Marte adverti ela uma puta safada

Ele um pobre Espadachim

$$
\text { (...) }
$$

Buscais por lá quem vos creia que um filho da puta vil não pode ter boas manhas, nem quem o segue bom fim.

(SOARES, Antônio da Fonseca. Romance 11, in. Ms.2998)

Eu nunca comadres vi gritarem como em açougue

e no cabo as espetadas

dão bofetadas que chovem

Putas se chamam, e disputam

No que sabem quanto podem

e saindo tudo a praça não fica nada no fole

(SOARES, Antônio da Fonseca. Romance 80, in. Ms.2998) 
Proferir calões, erotizar signos de pertencimento da Igreja Católica, blasfemar, expor explicitamente imagens pornográficas, insultar autoridades parece ser a "palavra" de ordem na enunciação satírico-burlesca. Dos enunciados-poéticos em questão, surge um modo de enunciar grosseiro e inculto das camadas populares. A despeito disso, o ethos que deles emerge está investido na imagem de homem honesto, cuja racionalidade é destituída devido a algum desvio moral de seu interlocutor. É o que ocorre a seguir:

\section{Romançe 54}

Minha santinha esse instante me chegaram novas vossas sem ser isto dita minha me pareceu cousa nova Ventura grande parece mas eu não me admiro agora pois que tenho em vossa graça

a ventura por devota

Sabe o céu com quantas ânsias nos ermos da minha alcova de não guardar essas regras fez penitencia a memória, Mas hoje que ei de ir a ver-vos anda a minha alma tão doida que com ser toda cartuxa se vai saindo das conchas He tal o gosto que tenho que crede que nesta hora nas voltas do touro temo dar me o miolo uma volta (...) 
No enunciado, há a erotização de um signo de pertencimento do discurso religioso, o item lexical "santa", num tom irônico. Há tambem a relação conflituosa de um sujeito enunciador tomado pelo desejo e em vias de perder a razão. Entre o gracejo irônico e a perda da racionalidade, o jogo metafórico que atualiza o sentido de palavras pertencentes a outros campos discursivos e o conflito razão/ instinto, há outro mecanismo de autonomia do discurso literário constituinte seiscentista: a ideia de que todo discurso literário deve, de uma só vez, deleitar e instruir. Deleitar pela maestria no manejo do código de composição e instruir pela transmissão de algum ensinamento. No caso da identidade enunciativa satírico-burlesca, o objetivo é denunciar ações viciosas.

Nesse sentido, as especificidades enunciativas da identidade enunciativa satírico-burlesca fornecem as diretrizes de um processo de autoralidade. O autor-responsável Antônio da Fonseca Soares, investido no estatuto enunciativo de poeta burlesco, faz emergir no enunciado um ethos conflituoso cindido entre a razão e o desejo, a urbanidade e a grosseria. De outro modo, esse mesmo nome evoca a imagem social do poeta burlesco. A engenhosidade em manipular o código retórico-poético o aproxima da fonte fundadora e a trajetória no campo literário o aproxima da imagem social do poeta burlesco. Tais articulações são essenciais para a ascensão de um auctor.

De certo modo, todo aquele que se propõe a produzir determinado gênero de discurso literário é um auctor em potencial. Todavia, se todo texto literário implica por natureza um responsável, apenas um número muito restrito atinge o estatuto de auctor. Nesse caso, há três questões a serem levadas em conta. A primeira diz respeito a trajetória do escritor no campo literário, sua filiação aos membros das comunidades discursivas e sua compatibilidade com os convenções históricas sobre o que é ser um escritor. A segunda é concernente à vocação enunciativa do escritor: é preciso se distinguir entre os demais enunciadores como uma identidade criadora singular. A terceira se refere a comentários posteriores sobre a produção discursiva em torno de um autor-responsável. Nesse sentido, os critérios de avaliação de uma obra serão pautados conforme seu enquadramento ao regime de autoria e também conforme o aspecto valorativo dos gestos autorais.

Há muitos discursos, cujo autor-responsável figura como Antônio da Fonseca Soares. O trabalho documental de Pontes (1950) mostra a grande quantidade de romances atribuídos a Antônio da Fonseca Soares espalhados por arquivos portugueses, a saber: BNL- Biblioteca Nacional de Lisboa; ANTT - Arquivo Nacional da Torre do Tombo; BPMP- Biblioteca Pública Municipal do Porto; BGUC - Biblioteca Geral da Universidade de Coimbra; BPB - Biblioteca Pública de Lisboa.

No dicionário Bluteau (1728), o verbete da palavra pechelingue traz, como exemplo de uso desse item lexical, um enunciado poético de autoria de Antônio 
da Fonseca Soares. A apresentação de um nome de autor no verbete de dicionário não é por acaso. Ela aciona uma função-autor no sentido de atuar como autoridade legitimadora da expressão linguística.

Aguiar e Silva (1971), reitera a manifestação dessa força autoral, ao afirmar existir alguns sonetos de Antônio da Fonseca Soares atribuídos ao Boca do Inferno na edição das Obras de Gregório de Matos (1923-1933), da Academia Brasileira de Letras. A respeito de tal constatação, a questão que fica é a seguinte: os sonetos seriam de fato de Antônio da Fonseca Soares ou seriam de autoria de Gregório de Matos, mas escrito à maneira fonsequiana?

Contudo, a produção discursiva burlesca fonsequiana foi sendo alvo de julgamentos depreciativos à medida que era lida a partir de outras posições estéticas. Comentadores posteriores fundamentaram as críticas em juízos de valor negativos baseados em quadros hermenêuticos distintos do período barroco. Os modos de leitura tinham como critério principal a clareza da linguagem e juízos morais em relação às tematizações eróticas.

Nesse caso, o discurso literário constituinte, embora crie a ilusão de autonomia e busque mecanismos para se autoafirmar, é muitas vezes atravessado por discursos que replicam o código ético-político dominante. Desse modo, em muitos comentários que giram em torno das grandes obras ou de auctores essa interdiscursividade emerge de maneira oculta ou, às vezes, explícita nos critérios de avaliação.

Maingueneau (2010, p.31) afirma que o autor só alcançará o status de auctor "apenas se terceiros falam dele, contribuam para modelar uma imagem de autor". Se voltarmos os olhos novamente para o Antônio da Fonseca, autor de discursos burlescos, veremos que isso ocorre. Contudo, desde o início, sua imagem é eclipsada pela de seu nome religioso, Frei Antônio da Chagas. Desde sempre, os critérios para tal distinção foram pautados muito mais em juízos morais do que estéticos.

Contudo, no século XVII, os discursos burlescos fonsequianos não foram consumidos pelo fogo, como pediu o P. Godinho (1762), biógrafo de Frei Antônio das Chagas. A justificativa para isso está na hipótese de que a recepção seiscentista sabia definir as qualidades inerentes a cada posição estética e, julgava como bons, os discursos da produção burlesca de Antônio da Fonseca Soares.

O nome do autor-responsável na condição de auctor está investido da função-autor, no sentido de ser equivalente a uma descrição. Conforme Foucault (2013), “quando se diz 'Aristóteles' emprega-se uma palavra que é equivalente a uma descrição ou uma série de descrições definidas, do gênero de: 'o autor das Analíticas', ou: 'o fundador da ontologia' etc.”. Quando pensamos em Antônio da Fonseca Soares também é inevitável que isso ocorra: trata-se do Capitão e 
poeta burlesco dos romances joco-sérios e eróticos; do estroina e namorador, "mui conhecido e louvado, e procurado de muitos" (VERNEY, 1950, 264), "do mais glorioso aluno de Apolo, mais discreto amante das Muzas e digníssimo corifeu das graças" (Ms. 6269, BNL), autor de abundantes poesias escabrosas que corriam manuscritas (PIMENTEL, 1889); "poesia de esgoto, uma espécie de maré-baixa, mal cheirosa, que inunda as miscelâneas seiscentistas” (PONTES, 1950).

A descrição constitutiva presente na instância auctor é uma espécie de sedimentação dos discursos em torno do nome do autor-responsável e da produção discursiva relacionada a esse nome. Tal produção, ao mesmo tempo, legitima e é legitimada pelo auctor. O que se convencional chamar de obra nos estudos literários, é o discurso ou conjunto de discursos em torno dessa força autoral. O nome Antônio da Fonseca Soares relacionado à produção discursiva burlesca está investido desse fator descritivo que chama para si um conjunto de discurso, conferindo-lhes unidade e identidade.

\section{CONCLUSÃO}

A noção de discurso constituinte procura dar conta das especificidades de certas unidades discursivas com características distintas dos discursos institucionalizados. Diferem-se destes porque possuem algumas regularidades. Entre elas, está a de constituírem as condições de sua imergência e gerirem sua própria existência no cerne do interdiscurso. Para isso, é preciso se estabelecer como o único detentor do archeion, da fonte de poder, que ao mesmo tempo é arquivo, memória e autoridade. Trata-se de um jogo de autolegitimação constante, pelo qual se estabelece um ambiente instável de pertencimento não pertencimento ao universo discursivo, ou seja, a condição de existência de tais discursos é paratópica.

Além disso, os discursos constituintes se organizam em campos configurados em zonas discursivas com normas de funcionamentos particulares: os posicionamentos. Eles também dão origem a uma série de práticas sócio-discursivas articuladas por comunidades restritas, as quais gerenciam os modos de produção, recepção e circulação de discursos. A condição paratópica de tais discursos subjaz as práticas discursivas e faz da paratopia o "motor de criação". No caso específico do discurso literário constituinte, a trajetória dos escritores é marcada pelo pertencimento paradoxal aos espaços sociais. Daí a potencia de sentido presente na máxima: "o autor está na obra, assim como a obra está no autor".

As análises dos enunciados satírico-burlescos de Antônio da Fonseca Soares mostram como as normas enunciativo-discursivas do posicionamento e da identidade enunciativa determinam a produção literária e também a trajetória do escritor. Enquanto o posicionamento Barroco determina a estética da imitação e um 
comportamento parasitário em relação ao poder real na lógica do regime de mecenato; a identidade enunciativa satírico-burlesca soma a isso uma estética do riso, manipuladora de discursos proibidos, e uma atitude transgressiva no âmbito das relações sociais por parte do poeta burlesco.

Para tornar-se um auctor, a instância autoral precisa, de maneira paratópica, jogar com tais determinações. Toda instância criadora singular deve jogar com as formas de pertencimento/não pertencimento à sociedade e de obediência/desobediência às normas de autoralidade. Ao mesmo tempo, na lógica de funcionamento dos discursos constituintes, a posição enunciativa deve se estabelecer como porta-voz dos princípios que fundamentam o posicionamento e a identidade enunciativa.

No caso de Antônio da Fonseca Soares, poeta mundano, a recepção percebe tal dinâmica ao comentar sua produção de maneira elogiosa, pelo domínio do código poético-retórico. Contudo, paradoxalmente, a recepção também o legitima como auctor, ao criticá-lo com juízos de valor injuriosos, num registro ético-político. Isso porque a enunciação satírico-burlesca projeta uma imagem psicossocial do poeta burlesco, como um transgressor dos valores sociais vigentes.

Enfim, o percurso de análise busca mostrar que o discurso constituinte em sua especificidade pode servir de aparato teórico-metodológico para análise de enunciados literários. Pela apreensão da cena de enunciação, é possível vislumbrar normas enunciativo-discursivas e, a partir daí, descrever o processo de autoralidade desses discursos. Pensamos que é possível utilizar tal modelo para os demais discursos constituintes e, com isso, contribuir para ampliar as possibilidades de entendimento de tais práticas sócio-discursivas.

\section{REFERÊNCIAS}

ANGERMULLER, Johannes. Análise de discurso pós-estruturalista: as vozes do sujeito na linguagem em Lacan, Althusser, Foucault, Derrida e Sollers. Tradução Roberto Leiser Baronas, et al. Campinas: Pontes Editores, 2016.

AGUIAR E SILVA, Vitor Manuel Pires. Maneirismo e barroco na poesia lírica portuguesa. Coimbra: Universidade de Coimbra, 1971.

ARISTÓTELES. Arte retórica e arte poética. Tradução Antônio Pinto de Carvalho. Rio de Janeiro: Ediouro, [19-].

BLUTEAU, Raphael. Vocabulário portuguez e latino. Coimbra: Collegio das Artes da Companhia de Jesus, 1712-1728. Disponível em: <http: / /www.ieb.usp.br /online / index.asp>.

Charaudeau, Patrick \& MAINGUENEAU, Dominique. Dicionário de Análise do Discurso. Tradução Fabiana Komesu. São Paulo: Contexto, 2014. 
FOUCAULT, Michel. O que é um autor? In Estética: literatura e pintura, música e cinema. Manuel Barros de Mota (Org.). Tradução Inês Autran Dourado Barbosa. Rio de Janeiro: Forense Universitária, 2013.

GODINHO, Manuel. Vida virtudes, e morte com opinião de santidade do Veneravel Padre Frei Antonio das Chagas. Lisboa: Oficina de Francisco Borges de Souza, 1762. HANSEN, João Adolfo. A sátira e o engenho. São Paulo: Companhia das Letras, 1989. LOPES, André. O riso erótico em discursos burlescos de Antônio da Fonseca Soares. 2019. Tese (Doutorado em Língua Portuguesa) - Programa de Estudos Pós-Gradduados em Língua Portuguesa, Pontifícia Universidade Católica de São Paulo, São Paulo.

LOPES, Andre da Costa; NOGUEIRA, Andréa Scavassa Vecchia Nogueira. O luzir do discurso engenhoso: a noção de metáfora aguda segundo a preceptiva retórico-poética seiscentista. In MORAES, Carlos Eduardo Mentes; BULHÒES, Ricardo Magalhães (Org). Capítulos Lusoamericanos: História, Filologia, Literatura e Linguística. São Paulo: UNESP - Campus de Assis, 2019.

MAINGUENEAU, Dominique. Analisando discursos constituintes. Tradução Nelson Barros da Costa. Revista do Gelne, Natal, v.2, n.2, 2000.Disponível em <https://periodicos.ufrn.br/gelne/issue/view/520>

- O contexto da obra literária: enunciação, escritor, sociedade. Tradução Marina Apenzzeller. São Paulo: Martins Fontes, 2001.

_. Gênese dos discursos. Tradução Sírio Possenti. São Paulo: Parábola, 2008.

. Cenas de enunciação. São Paulo: Parábola, 2008b.

. Doze Conceitos em Análise do Discurso. Tradução Adail Sobral et al. São Paulo: Parábola, 2010.

. Discurso Literário. Tradução Adail Sobral. São Paulo: Contexto, 2012.

MALDONADO, Maria Hermínia. Antônio da Fonseca Soares (Frei Antônio das Chagas) Trinta Romances Inéditos. Boletim da Biblioteca da Universidade de Coimbra, Coimbra, v. 41, 1992, p. 407-496. Separata.

MIRANDA, Ana. Musa Praguejadora: a vida de Gregório de Matos. Rio de Janeiro: Record, 2014.

MUHANA, Adma. A epopéia em prosa seiscentista: uma definição de gênero. São Paulo: Unesp, 1997.

PIMENTEL, Alberto. Vida mundana de um frade virtuoso. Lisboa: Antônio Maria Pereira, 1889.

PONTES, Maria de Lourdes Belchior. Frei Antônio das Chagas: um homem e um estilo do século XVII. Bibliografia de António da Fonseca Soares (Frei António das Chagas). Lisboa: Universidade de Coimbra, 1950.

SANTIAGO, Silviano. Uma literatura nos trópicos. Rio de Janeiro: Rocco, 2000.

SOARES, Antônio da Fonseca. Manuscrito 2998 da Sala de Reservados da Biblioteca Geral da Universidade de Coimbra - [16-]. 
TESAURO, Emanuele. Tratado dos Ridículos. Tradução Cláudia de Luca Nathan. Campinas: CEDAE - IEL - UNICAMP, 1992.

VERNEY, Luís. Antônio. Verdadeiro método de estudar: volume 2. Lisboa: Livraria Sá da Costa, 1950. 